\title{
The lonely glutamine tree in the middle of the infinite critically ill forest
}

\author{
Panagiotis Briassoulis ${ }^{1}$ (D), Stavroula llia $^{1}\left[\mathbb{D}\right.$, Efrossini Briassouli ${ }^{2}$, Marianna Miliaraki ${ }^{1}$ (D) and George Briassoulis ${ }^{1^{*}}$ (D)
}

\section{Dear Editor,}

We read with great interest the article by Dr. Smedberg et al. addressing the issue of plasma glutamine status at intensive care unit (ICU) admission [1]. As indicated in their paper, hyperglutaminemia $(\geq 930 \mu \mathrm{mol} / \mathrm{L})$ at admission is an independent mortality predictor. There are issues that we want to highlight and comment on.

First, in this cohort of patients, $85 \%$ had liver disease at admission. The study lacks a non-liver failure hyperglutaminemic and/or a liver-failure non-hyperglutaminemic control group to examine metabolic pathways, amino acid kinetics, and compared outcomes. In a recent study in critically ill patients enrolled from three ICUs in South Africa, 14.2\% had high (median $898.9 \mu \mathrm{mol} / \mathrm{L}$ ) plasma glutamine levels. Patients with a diagnosis of liver failure had the highest glutamine levels. In this study, mortality was higher in the low $(<420 \mu \mathrm{mol} / \mathrm{L})$ compared to high ( $>420 \mu \mathrm{mol} / \mathrm{L})$ glutamine level $(62.2 \%$ vs. $37.8 \%)$ [2]. We have previously demonstrated that high doses of L-alanine-glutamine or L-glutamine did not induce any of the $\mathrm{T}$ helper (Th)1, Th2, and Th17 cytokines in either healthy or septic human PBMCs at 4 and $24 \mathrm{~h} \mathrm{[3].}$

Second, the main finding of the study is that hyperglutaminemia at ICU admission was associated with a more than twofold higher mortality rate at six months (46\%) compared to patients with normal or low plasma

This comment refers to the article available online at https://doi.org/10.1186/ s13054-021-03640-3.

*Correspondence: briasoug@uoc.gr; ggbriass@otenet.gr

${ }^{1}$ Pediatric Intensive Care Unit, Postgraduate Program "Emergency and Intensive Care in Children Adolescents and Young Adults", School

of Medicine, University of Crete, Section 6D (delta), Office 03, Voutes,

71003 Heraklion, Crete, Greece

Full list of author information is available at the end of the article glutamine concentrations at admission (18\%). But the high plasma glutamine concentration could have led to limit protein/amino acid intake in these patients. Why should an initial high glutamine level be associated with mortality at 6 months? The acute phase of critical illness is associated with variable patterns of plasma amino acid changes, characterized by decreasing, increasing trends, or no changes in plasma levels compared with the values found in healthy subjects [4]. As the disease progresses, the levels of different amino acids gradually decrease, increase, or fluctuate over time. We have previously shown that pediatric patients with septic shock (hospital mortality $22 \%$ ) had lower levels of glutamine on ICU day 3 (410 vs. $726 \mu \mathrm{mol} / \mathrm{L})$ and 5 (426 vs. $691 \mu \mathrm{mol} / \mathrm{L})$, compared to patients with non-infectious critical illness (mortality 4\%) [4].

Similar to other nutritional constituents, temporarily adapted to the acute phase of critical illness [5], hyperglutaminemia could have only been an epiphenomenon, obviously affected by acute liver damage at admission. Future explorations are thus encouraged to clarify the mechanisms underlying the metabolism of glutamine in critical illness-related organ failures.

\section{Reply from the authors}

\section{Marie Smedberg ${ }^{3}$, Inga Tjäder ${ }^{3}$, Olav Rooyackers ${ }^{3}$ and Jan Wernerman ${ }^{3}$ \\ ${ }^{3}$ Department of Anesthesiology and Intensive Care, CLINTEC, Karolinska Institute and Perioperative Medicine and Intensive Care, Karolinska University Hospital Huddinge Stockholm}

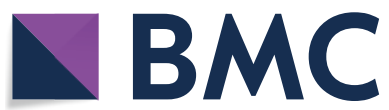

(c) The Author(s) 2021. Open Access This article is licensed under a Creative Commons Attribution 4.0 International License, which permits use, sharing, adaptation, distribution and reproduction in any medium or format, as long as you give appropriate credit to the original author(s) and the source, provide a link to the Creative Commons licence, and indicate if changes were made. The images or other third party material in this article are included in the article's Creative Commons licence, unless indicated otherwise in a credit line to the material. If material is not included in the article's Creative Commons licence and your intended use is not permitted by statutory regulation or exceeds the permitted use, you will need to obtain permission directly from the copyright holder. To view a copy of this licence, visit http://creativecommons.org/licenses/by/4.0/. The Creative Commons Public Domain Dedication waiver (http://creativecommons.org/publicdomain/zero/1.0/) applies to the data made available in this article, unless otherwise stated in a credit line to the data. 
We thank Drs Briassoulis et al. for their interest in and comments on our recent publication [1]. As stated, the glutamine tree is indeed lonely in the infinite critically ill forest. The main reason for us to publish this piece of information was the lack of published materials over hyperglutaminemia in the adult critically ill population. Our first observation of admission hyperglutaminemia as a risk factor for mortality contained only 8 subjects [6]. The present study contains 26 subjects, or 19 subjects if the postoperative liver transplant patients with zero mortality are excluded. The small number of subjects makes statistical comparisons hazardous. In both these studies, we defined hyperglutaminemia for the critically ill as the cutoff (maximum of sensitivity + specificity) for 6-month mortality in a ROC curve including all study patients with an admission plasma glutamine value above the normal range for healthy subjects, which turned out to be identical $(930 \mathrm{umol} / \mathrm{L})$ in the two studies. The study by Blaauw et al. has a different design and contains a different patient cohort, but basically it confirms our results for the hyperglutaminemic subjects, although they use the upper normal level for healthy individuals to define hyperglutaminemia [2]. We agree with Drs Briassoulis et al. that prospective studies over the underlying mechanism behind the statistical connection between glutamine plasma concentrations and mortality outcomes in the critically ill are a future challenge for those of us that are interested in the "glutamine tree".

\section{Acknowledgements}

None.

\section{Authors' contributions}

$\mathrm{PB}, \mathrm{SI}, \mathrm{EB}, \mathrm{MM}$, and GB have contributed in all parts in producing the manuscript. All authors read and approved the final manuscript.

\section{Funding}

Not applicable.

\section{Availability of data and materials}

Not applicable.

\section{Declarations}

Ethics approval and consent to participate

Not applicable.
Consent for publication

All authors give the consent to publish.

\section{Competing interests}

All authors claim no competing interest or conflict of interest.

\section{Author details}

${ }^{1}$ Pediatric Intensive Care Unit, Postgraduate Program "Emergency and Intensive Care in Children Adolescents and Young Adults", School of Medicine, University of Crete, Section 6D (delta), Office 03, Voutes, 71003 Heraklion, Crete, Greece. ${ }^{2}$ First Department of Internal Medicine - Propaedeutic, National and Kapodistrian University of Athens, Athens, Greece. ${ }^{3}$ Department of Anesthesiology and Intensive Care, CLINTEC, Karolinska Institute and Perioperative Medicine and Intensive Care, Karolinska University Hospital Huddinge, Stockholm, Sweden

Received: 11 August 2021 Accepted: 12 August 2021

Published online: 17 September 2021

\section{References}

1. Smedberg M, Helleberg J, Norberg Å, Tjäder I, Rooyackers O, Wernerman J. Plasma glutamine status at intensive care unit admission: an independent risk factor for mortality in critical illness. Crit Care. 2021;25:240. https:// doi.org/10.1186/s13054-021-03640-3

2. Blaauw R, Nel DG, Schleicher GK. Plasma glutamine levels in relation to intensive care unit patient outcome. Nutrients. 2020;12:E402.

3. Briassouli E, Goukos D, Daikos G, Apostolou K, Routsi C, Nanas S, et al. Glutamine suppresses Hsp72 not Hsp90a and is not inducing Th1, Th2, or Th17 cytokine responses in human septic PBMCs. Nutrition. 2014;30:1185-94.

4. Spanaki AM, Tavladaki T, Dimitriou H, Kozlov AV, Duvigneau JC, Meleti E, et al. Longitudinal profiles of metabolism and bioenergetics associated with innate immune hormonal inflammatory responses and amino-acid kinetics in severe sepsis and systemic inflammatory response syndrome in children. JPEN. 2018;42:1061-74.

5. Briassoulis G, Ilia S. Vitamin D deficiency in sepsis: "body humors" imbalance or sepsis"epiphenomenon"? Crit Care Med. 2017;45:376-7.

6. Rodas PC, Rooyackers O, Hebert C, Norberg A, Wernerman J. Glutamine and glutathione at ICU admission in relation to outcome. Clin Sci. 2012;122(11-12):591-7.

\section{Publisher's Note}

Springer Nature remains neutral with regard to jurisdictional claims in published maps and institutional affiliations.

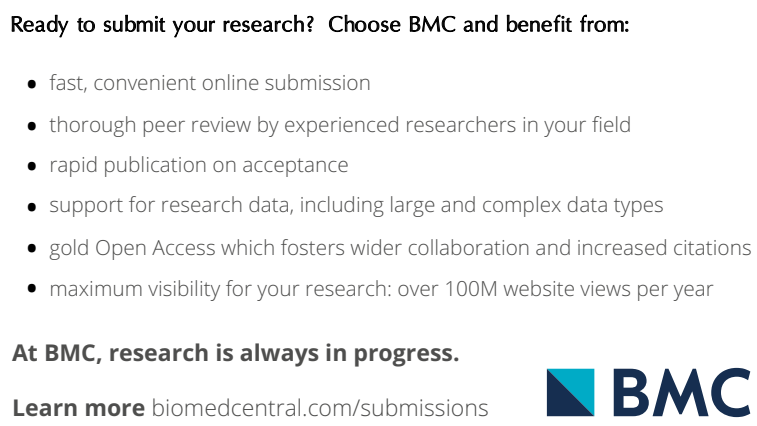

